
of Christian Minorities in Turkey

Author(s): Isaac E. Andakian

Source: Kyiv-Mohyla Law and Politics Journal 6 (2020): 45-72

Published by: National University of Kyiv-Mohyla Academy

http://kmlpj.ukma.edu.ua/ 


\title{
EU Enlargement, Conditionality, and the Protection of Christian Minorities in Turkey
}

\author{
Isaac E. Andakian \\ PhD student \\ Kennesaw State University, United States
}

\begin{abstract}
Turkey has had aspirations to join the European Union (EU) and be part of Europe since 1958. The most recent three EU enlargement rounds in 2004, 2007, and 2013 included most Eastern European countries and kept Turkey aside. Turkey has to comply with numerous enlargement conditionalities imposed by the EU to obtain the status of potential membership eligibility. Among these conditionalities are the Copenhagen criteria, which include but are not limited to the respect of minority rights as an inseparable part of Copenhagen's political criterion. This essay discusses the respect of minority rights in Turkey as a conditionality for its EU accession and focuses on the non-Muslim Christian minorities, namely Armenian Orthodox and Greek Orthodox minorities. The findings of this essay present and demonstrate the persecutions and intolerance these minorities have encountered and still encounter in their everyday life within Turkish society by the current Turkish government and its predecessors. As a result, this essay argues that Turkey does not comply with the 'respect of minority rights' requirement as prescribed by the Copenhagen criteria, a prerequisite for its EU accession. Consequently, Turkey is not eligible for EU accession from the 'respect of minority rights' perspective as it does not fulfill the latter condition.
\end{abstract}

Key Words: EU conditionality, EU accession, Turkey, minority rights, Armenian Orthodox, Greek Orthodox

\section{(7)}

\section{Introduction}

Turkey has always been keen and interested to adopt democratic-European values through the formation of a laic and presumably democratic state in reflection of its European rather than Islamic identity. Turkey's European identity emerged with the Turkish state's formation with Ataturk, who "transformed the Ottoman monarchy into a nation-state modeled on the European example." 'Turkey took many steps towards reflecting its European identity and getting closer to its potential EU membership through becoming a member of the Council of Europe (CoE) in 1949, the North Atlantic Treaty Organization (NATO) in 1952, Organization for Economic Co-operation and

$1 \quad$ Cemal Karakas, “Turkey: Islam and Laicism Between the Interests of the State, Politics, and Society," PRIF Reports No. 78, 2007. 
Development (OECD) in 1961, and Organization for Security and Co-operation in Europe (OSCE) in 1973. The European Economic Community and Turkey signed an Agreement establishing an Association between the European Economic Community and Turkey (1963) (OJ L 217, 29.12.1964) and its Additional Protocol of 23.11.1970 (OJ L 293, 29.12.1972). In December 1995, The European Economic Community and Turkey signed Decision 1/95 of the Association Council of 22.12.1995 (OJ L 35, 13.02.1996) on implementing the final phase of the Customs Union. Following that, during the Helsinki Council of 1999, Turkey was accepted as a candidate country. Finally, the EU accession negotiations started with Turkey on October 3, 2005.

If not many, Turkey is still a few steps away from achieving its accession to the EU since it still needs to comply with many requirements and satisfy many conditions imposed by the EU. Among these conditions are satisfying the four criteria adopted by the Copenhagen Council in 1993. The Copenhagen Council imposed four necessary conditions for any Central and Eastern European Country (CEECs) accession, including Turkey and the Balkans. Among these four conditions lies the political criterion, which requires that the candidate country meets four requirements, including "stability of institutions guaranteeing democracy, the rule of law, human rights and respect for and protection of minorities." It is the "respect for and protection of minorities" that this essay will highlight as one of the four main conditionality requirements for Turkey's EU accession in any future round of enlargement. In doing so, this essay tries to answer the following questions: who are the minorities in Turkey? Do they have rights within the state, and can they practice their rights freely per international norms? To what extent are these rights protected and guaranteed by the Turkish government? In addressing the third question, this essay narrows the examination to focus on the non-Muslim Christian minorities in Turkey, particularly the Greek Orthodox and Armenian minorities, in accordance with the Lausanne Treaty of 1923.

The structure of this article is divided into four main parts. The first part considers EU enlargement and the "minority rights" conditionality for Turkey. The second part considers the respect for and protection of Non-Muslim Christian Minorities in Turkey as part of the political conditionality stated in the Copenhagen criteria of 1993. In that second part, I assess the Turkish-nationalist mentality/ideology that shaped the negative image of the minorities on the one hand and, on the other, the tense and often discriminatory relationship of the Turkish government and society with these minorities since 1923. In the third part, I mention some significant aspects of the current persecution of the non-Muslim Christian minorities and their rights' infringement by the Turkish government. These basic rights are essential and significant to the minorities' existence, continuity, and protection. The non-Muslim Christian minority rights' infringement targets the latter's legal status (legal capacity and the socio-religious entities, properties, and institutions including but not limited to schools and monasteries), right to property and inheritance, and schools. In the third part, I also specify some of the most serious and damaging violations of the 'Armenian Orthodox' and 'Greek Orthodox' minority rights and their current situation in Turkey. I examine whether there is hope for the future of the non-Muslim minorities in Turkey in the light of some empirical and factual evidence in the fourth part. 


\section{EU Enlargement and Minority Rights Conditionality Requirements for Turkey}

According to Gateva, ${ }^{2}$ the EU established a strong correlation and interdependence between the fulfillment of specific conditions and advancements in any candidate country's accession process. Consequently, the relationship between the EU and Turkey best resembles a carrot-and-stick policy because every time Turkey complies with the minimum conditionality requirements, the EU asks for more and pushes the limits of its imposed conditionality a bit further. As a result, EU-Turkish relations have witnessed many ups and downs since Turkey's application to the European Economic Community in 1987 as it has "trekked an erratic path, oscillating between amity and enmity." ${ }^{3}$ As Emmert and Pertovic ${ }^{4}$ describe it, the EU has repeatedly sidelined Turkey for mostly political reasons and is still on and off in negotiations today. During the Luxembourg summit in 1997, Turkey was denied the candidacy status because of its non-compliance with human rights standards, including the respect of minority rights. Two years later, during the Helsinki summit in 1999, Turkey was formally granted a candidate country's status, and Turkey's accession negotiations started on October 3, 2005. However, in mid-2017, the European Parliament voted to suspend Turkey's EU accession negotiations due to the violation of the rule of law by the Turkish authorities by expanding President Recep Tayyip Erdogan's powers following a one-year crackdown on his opponents who led a failed coup-d'états in July 2016.5

The EU Enlargement Strategy and Main Challenges for 2006-2007 states that EU enlargement policy is based on "three basic principles: consolidation of commitments, conditionality and communication." ${ }^{-}$Consequently, conditionality is one of the pillars of the Commission's enlargement strategy. Enlargement has a crucial impact on Turkey's democracy and domestic politics. Killick ${ }^{7}$ defines conditionality as being the "set of mutual arrangements by which a government takes, or promises to take, certain policy actions, in support of which an international financial institution or other agency will provide specified amounts of financial assistance." Therefore, one can conclude from this definition that conditionality has two ends, where the government's

Eli Gateva, “Post-Accession Conditionality: Support Instrument for Continuous Pressure?" KFG Working Paper No. 18, 2010.

Ersin. Kalaycıoglu, "The Political Criteria: Fair or Strict Conditionality?" Paper presented at 'the EU and the 2004 milestone: Is this time for real?' Conference, March 14-15, 2003. Oxford, UK, 2003. Frank Emmert and Sinisa Petrovic, "The Past, Present, and Future of EU Enlargement," Fordham International Law Journal 37, no. 5 (2014), https://ir.lawnet.fordham.edu/ilj/vol37/iss5/2. Ece Toksabay and Tulay Karadeniz, "EU Parliament Calls for Turkey Accession Talks to Be Suspended," Reuters, last modified July 6, 2017, https://www.reuters.com/article/us-turkey-euparliament/eu-parliament-calls-for-turkey-accession-talks-to-be-suspended-idUSKBNigRig4. Commission, "Communication from The Commission to The European Parliament and The Council: Enlargement Strategy and Main Challenges 2006-2007," COM (2006) 649, 2006, 5 . Tony Killick, Aid and the Political Economy of Policy Change (London: Routledge, 1998), 6. 
compliance with certain policy changes represents one end and the receipt of benefits represents the other end. Generally speaking, conditionality can be either positive or negative. In the former case, countries complying with promoting human rights and democracy are rewarded with economic benefits. In contrast, in the latter case, countries violating human rights and democracy or having a record of undemocratic practices are punished through economic sanctions. ${ }^{8}$ However, concerning the EU's external relations and enlargement policy, conditionality has always been positive since it aims to develop social, political, and economic progress with an effective motivation system. The EU has identified conditionality as a "functional cooperation or pre-accession method of integration, where guidance and strict rules are needed to provide effective convergence with the EU and to support transitional societies in the modernization process," ${ }^{9}$ Moreover, Usul10 argues that conditionality is a foreign policy tool used by the EU or any other "rich Western club" to promote democracy and respect for human rights in countries with poor human rights and democracy records. In return for their compliance in promoting human rights and democracy, countries receive economic incentives in the form of either economic aid or "club membership," such as EU membership that provides accessibility to consumers' gigantic market.

Democratic reforms in Turkey as prescribed by the EU conditionality requirements are not easy to fulfill for various reasons, as highlighted and discussed in the following paragraphs. Rumford argues that "the path to democratic reform and the adoption of the EU norms of human rights and democratization has not been a smooth one." 11 There are two obvious reasons for that. The first of which is that one cannot expect such an oligarchic state, so accustomed to holding power, to consent to share its sovereignty as a member of the EU. The second reason is that the fear of the unknown and the "other" is so dominant in the Turkish society that it produces symptoms of resistance to change at all levels. ${ }^{12}$ It is difficult for Turkey to adjust its constitution, regulations, and laws with the EU requirements and conditionalities. It is even more difficult to practice these adjustments and adaptations in an open-minded manner and broadened tolerant mentality since "in the shift from nation-state societies [Turkey] to

8 Carolyn Baylies, “Political Conditionality' and Democratisation," Review of African Political Economy 22, no. 65 (1995), doi:10.1080/03056249508704143.

V. Veebel, "European Union's Positive Conditionality Model in Pre-Accession Process," TRAMES:

A Journal of the Humanities \& Social Sciences 13, no. 3 (2009): 207, doi:10.3176/tr.2009.3.02.

10 Ali R. Usul, Democracy in Turkey: The Impact of EU Political Conditionality (London: Routledge, 2011).

11 Chris Rumford, "Resisting Globalization?: Turkey-EU Relations and Human and Political Rights in the Context of the Cosmopolitan Democratization," International Sociology 18, no. 2 (2003): 380, doi:10.1177/0268580903018002004.

12 Hrant Dink, "The Water Finds Its Crack: an Armenian in Turkey," Open Democracy, last modified January 19, 2012, https://www.opendemocracy.net/en/europe_turkey_ armenia_3118jsp/. 
cosmopolitan society [the EU] international law frequently bypasses national authority and addresses individuals directly." ${ }^{13}$

It is not sufficient to make the changes on paper (formal institutional rule); it has to be made in practice (informal rule). For example, the mandatory declaration of religion on Turkish identity cards (IDs) was abolished in April 20o6. However, "the state continues to ask citizens to declare their religion. Non-Muslims who leave the section blank are therefore just as vulnerable as if they stated their religious affiliation." 14 Moreover, Turkish authorities still codify minorities with special "secret" 'race codes.' However, such a practice is strictly inconsistent with the protection of minority rights conditionality because it makes the identification of minorities easy, and therefore they can be subject to persecution and discrimination.

As a result of this race coding policy, "Greeks are classified as '1', Armenians are coded as '2', and Jews are notated as ' 3. .' 15 Secret race codifications could be used for various vicious activities. That is a practical example of the continuation of the discriminatory attitudes and actions towards the non-Muslim minorities in Turkey, despite its formal abolishment on paper. It was not done in an "institutionalized" manner or as a result of democratic consolidation from a bottom-up process. Instead, it was theoretically but not practically done to comply with democratic reforms for minority rights as conditionality requirements for EU accession. According to Dimitrova, "if formal and informal rules remain different and do not align, institutionalization will not take place. In this case, the newly adopted formal rules will remain rules-on-the-books rather than rules-in-use and will not affect the behaviour of actors." 16 Therefore, as long as the above-mentioned formal abolition of religious affiliation from Turkish IDs is not aligned with the state actors' informal behavior, the abolition will remain a rule-onpaper. It will accordingly be a "formal structure without substance" rather than being a rule-in-use and practice.

The incentive of a potential full EU membership is driving the Turkish government to adopt some reforms, which are superficial and not profound or essential. When such reforms are related to minority rights, the membership conditionality's effectiveness in driving the reforms gets slower, not to say that it stops completely, because compliance with minority conditionality is at minimum levels. That could be caused by the belief that promoting and supporting minority rights in Turkey is "considered as conspiracy

13 Rumford, "Resisting Globalization?: Turkey-EU Relations and Human and Political Rights in the Context of the Cosmopolitan Democratization," 384.

14 Dilek Kurban, “A Quest for Equality: Minorities in Turkey,” Minority Rights Group International Report, United Kingdom, 2007.

15 Hurriyet Daily News, “Turkish Interior Ministry confirms 'race codes' for minorities," Hürriyet Daily News, last modified August 2, 2013, www.hurriyetdailynews.com/turkish-interiorministry-confirms-race-codes-for-minorities.aspx?pageID $=238 \& \mathrm{nID}=51898 \&$ NewsCatID $=339$.

16 Antoaneta Dimitrova, "The New Member States Of The EU In The Aftermath Of Enlargement: Do New European Rules Remain Empty Shells?," Journal of European Public Policy 17, no. 1 (2010): 138, doi:10.1080/1350176o903464929. 
against or betrayal of the state by nationalists and some public officials." 17 This cautiousness towards minorities in Turkey is best reflected in the way Turkey dealt with relevant international treaties such as the International Covenant on Civil and Political Rights (ICCPR) and the International Covenant on Economic, Social and Cultural Rights (ICESCR). Turkey signed both treaties in 2000 and ratified them both in 2003 after registering reservations to Article 27 of the former and paragraphs (3) and (4) of Article 13 of the latter, all of which were reservations in respect of minority rights. ${ }^{18}$

The Council strictly used conditionality partially to suspend Turkey's EU membership bid when the Council decided in December 2006 "to suspend 8 of Turkey's 35 negotiating 'chapters' because of its failure to open its ports to Greek Cypriot vessels and planes." ${ }^{19}$ When Turkey refused to open its ports to Greek Cypriot vessels and planes, Cyprus had become a member of the EU. Since the EU is obliged to protect its members' interests, including that of Cyprus, it sanctioned Turkey for its decision by suspending the eight chapters discussed above. According to Yackley, ${ }^{20}$ many EU member states who are moderate opponents to Turkey's EU accession would prefer to see Ankara failing to comply with the conditionality requirements, grow tired of trying, and withdraw from the entire EU accession process voluntarily. Consequently, these EU states provoke Turkish nationalists by raising specific issues rejected highly by the Turkish community, including the division of Cyprus and the Armenian Genocide of 1915, both of which are not directly part of the acquis. Therefore, fortunately for Ankara, "both the Armenian issue and that of Cyprus lie fully outside the acquis." ${ }^{21}$ In other words, Ankara is fortunate enough that the conflict over the north of Cyprus and Turkey's refusal to recognize the Armenian Genocide are not part of the acquis because otherwise, they would have made Turkey's accession to the EU almost impossible due to the sensitive nature of both issues to the Turkish society.

Protection of minority rights is an inseparable and exclusive part of the Copenhagen Political Criterion, and the EU addresses it as such. However, limiting minority rights to the Copenhagen Political Criterion limits the EU's influence on enhancing, promoting, and supporting minority rights since the EU's capacity to influence these rights remains within the scope of Enlargement policy only. The EU has required the respect for and protection of minority rights conditionality on Turkey's accession for a long time through the Maastricht Treaty (1992), the Copenhagen Criteria

17 Kurban, "A Quest for Equality: Minorities in Turkey," 7.

18 Commission, “2003 Regular Report on Turkey’s Progress Towards Accession,” SEC (2003) 1212 Final, 2003, 38 .

19 Adele, Brown, and Attenborough, Michael. "EU Enlargement: The Western Balkans." House of Commons Library Working paper o7/27, 2007, 16.

20 Joseph Yackley, "Turkey, The EU and Democracy: How Public Opinion Divides Ankara and Brussels," last modified 2008, https://www.files.ethz.ch/isn/50025/17_casestudy_ turkeyandtheeu.pdf. 
(1993), and the Amsterdam Treaty (1997), all of which are codified under article 6 part 1 of the Treaty of the European Union. ${ }^{2223}$

Although Article 6 of the TEU foresees the existence of smoothly performing institutions of democracy and the rule of law, which uphold human rights and the protection of minorities, the EU still has not established its own minority standards. Moreover, the EU has not developed a minority standard for the acquis communitaire or the EU member states beyond the principle of non-discrimination. As a result, the EU refers to the standards developed and adopted by other European organizations, including the Council of Europe ( $\mathrm{CoE}$ ) and the Organization for Security and Cooperation in Europe (OSCE). ${ }^{24}$ According to Galbreath and McEvoy, ${ }^{25}$ the EU, CoE, and OSCE have interdependent reliability on each other's minority rights standards through the Copenhagen criteria for the EU, the Framework Convention for the Protection of National Minorities (FCNM) for the CoE, and the OSCE guidelines and the OSCE High Commissioner on National Minorities. Moreover, the OSCE has provided the EU with a "security-based rationale or justification for minority protection [...]"26 in terms of linking minority rights to regional (in)stability due to the tensions in State-minority relations. ${ }^{27}$ Although CoE's role in more evident in the EU post-accession phase in monitoring minority rights, all the Regular Reports and yearly "Progress Reports" about candidate or potential candidate states would include a reminder about signing and ratifying the FCNM. ${ }^{28}$ Therefore, since 1998 the EU kept on reminding Turkey through the Commission's yearly progress reports ${ }^{29}$ used to monitor conditionality, including the conditionality of respect for minorities, that it had to sign the Framework Convention

22 Robertas P. Docent, "The Enlargement of The European Union and the (Non) Membership of Turkey," European Scientific Journal 10, no. 22 (2014), doi:10.19044/esj.2014.vion22p\%25p. E. J. Zurcher and H. Van Der Linden, The European Union, Turkey and Islam (Amsterdam: Amsterdam University Press, 2004).

24 Edina Szocsik, "The EU Accession Criteria in the Field of Minority Protection and the Demands of Ethnic Minority Parties," Journal on Ethnopolitics and Minority Issues in Europe:JEMIE 11, no. 2 (2012).

David J. Galbreath and Joanne McEvoy, “How Epistemic Communities Drive International Regimes: The Case of Minority Rights in Europe," Journal of European Integration 35, no. 2 (2012), doi:10.1080/07036337.2012.692117.

26 Gwendolyn, Sasse. "EU Conditionality and Minority Rights: Translating the Copenhagen Criterion into Policy." European University Institute (EUI) Working Paper RSCAS, 2005/16. Italy: EUI, 2005, 3. David J. Galbreath and Joanne McEvoy, The European Minority Rights Regime: Towards a Theory of Regime Effectiveness (Hampshire: Palgrave Macmillan, 2012).

28 Gwendolyn Sasse, "The politics of EU conditionality: the norm of minority protection during and beyond EU accession," Journal of European Public Policy 15, no. 6 (2008), doi:10.1080/13501760802196580. Sule Toktas, "EU enlargement conditions and minority protection: a reflection on Turkey's non-Muslim minorities," East European Quarterly 40, 
on the Protection of National Minorities, the European Charter for Regional and Minority Languages, and other international treaties related to minority rights. The EU also recommended that Turkey cooperates with the OSCE High Commissioner on National Minorities. ${ }^{30}$

Fulfilling the EU accession goal has inspired Turkey to make many reforms in 2001 and 2004 by amending its 1982 constitution. Consequently, Turkey undertook a package of 34 amendments in conformity with the EU conditionality, the requirements of the acquis, and the recommendations of the progress reports. According to the EU Commission, "in both the Balkans and Turkey, the effectiveness of conditionality in driving reforms depends on maintaining a credible political perspective for eventual integration into the Union. Aspirant countries can best sustain public support for bold and often painful reforms when the EU supports them, works with them, and keeps its own promises." 31

Although the Europeanization process in domestic law reforms also included minority rights in Turkey, it did not address the minority rights issues profoundly, openly, and honestly. These reforms regarding minority rights were not the result of Turkish contentment or persuasion. Instead, it was EU driven due to the Madrid European Council of 1995, which required "substantial administrative reforms in the candidate countries." 32 Therefore, these reforms resulted from EU imposed requirements and not the Turkish acceptance of not discriminating against non-Muslim Christian minorities and treating them equally with other Turkish citizens in accordance with international treaties and laws.

\section{The Extent of "Respect for and Protection of" Christian Minorities in Turkey since 1923}

Turkey is a mosaic of different identities and cultures, including religious, ethnic, and linguistic identities. ${ }^{33}$ Many minorities, including the Greek Orthodox, Armenians, Assyrians, Bulgarians, Alevites, Ezidis, Jews, and Kurds, have lived in Turkey for a long time.

Non-Muslim minorities in Turkey were discriminated against during the Ottoman era through the "millet" system and continued to be so after establishing the Turkish

no. 4 (2006): 507, http://citeseerx.ist.psu.edu/viewdoc/download;

jsessionid $=$ oF9AB655138BE3BoAAo26Fo842D4B36o?doi=10.1.1.716.934\&rep=rep1\&type=pdf.

Commission, "Regular Report on Turkey's Progress Towards Accession," COM (2002) 700 Final, 2002.

31 Commission, "Communication from the Commission—2005 enlargement strategy paper," COM (2005) 0561 Final, 2005, 3.

32 Antoaneta Dimitrova, "Enlargement, Institution-Building and the EU's Administrative Capacity Requirement," West European Politics 25, no. 4 (2002): 178, doi:10.108o/713601647.

33 Nigar Karimova, and Edward Deverell, "Minorities in Turkey," Occasional papers No. 19, the Swedish institute for international affairs, Stockholm, The Swedish Institute of International Affairs, 2001, 8. 
state on the ruins of the Ottoman Empire. The "millet" system is a "generalized system of imperial toleration and intense negotiation" with the heads of religious communities of the Jewish, Greek Orthodox, and Armenian communities by allowing them some autonomy on personal matters, but also "ensuring that they remained under the control of the state." ${ }^{34}$ During the post-WWI era, the victorious states obliged the defeated and newly formed states to guarantee ethnic, linguistic, and religious minorities' rights. Therefore, the requirement of minority protection was imposed on Turkey in the Treaty of Sèvres followed by the Lausanne Treaty in July 1923. The Lausanne treaty defined minorities through Articles 37 to 45 as being "non-Muslim minorities." The Turkish government limited the Lausanne minorities to the Greek Orthodox, Armenian Orthodox, and Jewish communities. Therefore, the officially and publicly recognized minorities in Turkey are the ones that are mentioned in the Lausanne Treaty based on the religious criterion. In other words, linguistic and ethnic minorities officially do not exist in Turkey. Consequently, all the Muslim population of Turkey, even those with different ethnic or linguistic backgrounds, including the Kurds and the Alawites, were categorized as "Turks" and became subject to homogenization policies. ${ }^{35}$

The milestone for establishing the modern Turkish state with Ataturk was the nationalist notion of creating a "homogeneous and unified community as the basis of their [Turk's] rule and legitimacy." ${ }^{36}$ However, Turkey's non-Muslim minority's presence was in fundamental conflict with the new nationalist ethos resembled by ethnic nationalism based on Turkishness. ${ }^{37}$ Therefore, the minority obstacle had to be addressed and removed, especially after the Turkish state has failed to overcome the segregation of non-Muslim minorities and integrate them into the nation as citizens with equal rights. Non-Muslim minorities were not accepted as natural members of the Turkish nation. They were considered the "undesirable others", who remained outside the Turkish Muslim nation's mainstream identification category.38 "While the Muslim Turks have been the 'we', the non-Muslim minorities have been considered as 'the other' and have been rather perceived as 'domestic foreigners.'” 39 Turkish society

34 Karen Barkey and George Gavrilis, "The Ottoman Millet System: Non-Territorial Autonomy and its Contemporary Legacy," Ethnopolitics 15, no. 1 (2016): 24, doi:10.1080/17449057.2015.1101845.

Kurban, "A Quest for Equality: Minorities in Turkey."

36 Resat Kasaba, "Kemalist Certainties and Modern Ambiguities," in Rethinking Modernity and National Identity in Turkey, ed. Sibel Bozdogan and ResatKasaba (Seattle: University of Washington Press, 1997), 27.

37 Rumford, "Resisting globalization?: Turkey-EU Relations and Human and Political Rights in the Context of the Cosmopolitan Democratization."

38 Ahmet Icduygu, SuleToktas, and B. Ali Soner, "The Politics of Population in a Nation-building Process: Emigration of Non-Muslims from Turkey," Ethnic and Racial Studies 31, no. 2 (2008): 359, doi:10.1080/01419870701491937.

39 Burcu Gultekin-Punsmann, Cengiz Gunay, Riva Kastoryano, and KıvançUlusoy, "Religious Freedom in Turkey: Situation of Religious Minorities," The European Parliament's Committee on Foreign Affairs - Policy Department External Policies, Briefing Paper, Brussels, European Parliament, 2008, 2. 
viewed those "undesirable others," who mainly comprised the non-Muslim minorities, either as "foreigners or internal enemies of the state." ${ }^{40}$ Instead, they should have been considered as "an aspect of pluralism that needed to be recognized and preserved as an asset to Turkish society, rather than perceived as a threat." ${ }^{41}$ This adverse sentiment towards the non-Muslim minorities was even taught to young school students through history textbooks until 2004, through which minorities were portrayed as "untrustworthy, traitorous and harmful to the state." ${ }^{42}$ Although the negative sentiment towards non-Muslims should have been removed from the textbooks by 2004, it is noticeable that remnants of persecution language and discriminatory rhetoric are still evident in some of the compulsory school textbooks and the first Diyanat Plan, a fiveyear plan set by The Directorate of Religious Affairs covering the period from 2010 to $2014^{43}$ Consequently, minorities were excluded from the Turkish national fabric and key public posts and offices as "there have still not been any non-Muslim bureaucrats in any state department except in arts institutions and universities." 44 They had to either assimilate and integrate into the Turkish nation after giving up their minority status or leave the country and emigrate as many Greeks and Armenians did.

Non-Muslim minorities in Turkey were discriminated against and persecuted through many means and during different periods. Sentiments of systematic persecution and discrimination against non-Muslim minorities could be found in Turkish socio-political life as early as the 1920s. According to Icduygu \& Soner, ${ }^{45}$ non-Muslim minorities were banned from certain professions in Turkey during the 1920 s and 193 os during which Muslim Turks replaced around 5000 employees from the Turkish Greek minority. Additionally, the Turkish government also blocked the path of non-Muslim minorities to public employment by resorting to the Law on Public Employment of 1926. The latter law “conditioned public employment with 'being Turkish,' not with 'being a Turkish citizen.' Hence, because non-Muslim minorities were considered Turkish only in terms

40 Harut Sassounian, "Sassounian: Istanbul Armenians Document Violations of Minority Rights in Turkey," The Armenian Weekly, last modified March 1, 2011, https://www.armenianweekly. com/2011/o3/o1/sassounian-istanbul-armenians-document-violations-of-minority-rights-inturkey/.

41 European Commission Against Racism and Intolerance, "ECRI report on Turkey 2011 — Fourth Monitoring Cycle," Council of Europe, last modified February 8, 2011, 30, https://rm.coe.int/ fourth-report-on-turkey/168o8b5c7e.

42 Commission, “Turkey: 2005 Progress Report,” COM (2005) 561 Final, 2005, 48.

43 Commission, “Commission Staff Working Document: Turkey 2014 Progress Report— accompanying the Document Communication from The Commission to The European Parliament, the Council, The European Economic and Social Committee and The Committee of The Regions," COM (2014) 700 Final, 2014.

44 Gozde Yilmaz, "Is there a Puzzle?: Compliance With Minority Rights in Turkey (1999-2010)," KFG working paper no. 23, Berlin, 2011, 12.

45 Ahmet Icduygu and B. Ali Soner, "Turkish Minority Rights Regime: Between Difference and Equality," Middle Eastern Studies 42, no. 3 (2006), doi:10.108o/oo263200500521370. 
of citizenship, the law, in practice, excluded non-Muslim citizens from the state sector, reserving it exclusively as a privilege for Turkish-Muslim citizens." ${ }^{46}$ This law remained in effect until its amendment in 1962. Even after amending the law, non-Muslim Turkish citizens were still blocked from public sector employment in practice. Although the official ban on employing non-Muslim minorities had been removed by 1962, many non-Muslim minorities lost their confidence in being hired for public positions.

Besides, Turkey also imposed a property tax for non-Muslims (also known as Varlik Vergisi Kanunu) from 1942-1944 in a clear violation of Articles 39 and 40 of the Lausanne Treaty, which ensures civil and political equality of Turkish nationals belonging to non-Muslim minorities with Muslims. The non-Muslim minorities were forced to pay a wealth/property tax, which "was arbitrarily imposed to bring about the impoverishment of non-Muslim segments of Turkish society." 47 This notion was later reflected in Prime Minister Sukru Saracoglu's speech delivered on August 5, 1942, in which he described the Turkish administration's program of the property tax and stated that his nation is "Turkish, pro-Turkish, and will always remain pro-Turkish."48 Another reflection of the Turkish institutionalized discriminatory policy against non-Muslim minorities is the founding of the "Secondary Committee for Minorities" by a secret decree in 1962 to carry out security surveillance on minorities, which remained operative legally until its abolition in January $2004 .{ }^{49}$

Under the auspices of the Turkish-Islamic Synthesis (TIS), the 1980 military coup triggered a turning point in Turkish politics because it introduced many changes that not only led to a "nationalization of Islam, but also to an Islamization of the nation. The military granted Sunni Islam a discrete and important role in the country's socio-political development; it was the "new" old source of legitimization for the Kemalist state". ${ }^{0}$ According to Kayaoglu, ${ }^{51}$ unlike Sunni Muslims, non-Muslim minorities were denied full legal and public recognition. The elites, who took critical positions in the Turkish government, controlled, raised, and mobilized a "Sunni identity as the official state ideology." 52 Therefore, Turkey's Sunni population was privileged, whereas the 'others', whether other Muslim minorities or non-Muslim minorities, were deprived

46 Icduygu and Ali Soner, 'Turkish minority rights regime: Between difference and equality,' 459.

Ari Esayan, "Armenians in Turkey Today: An Overview," Armenian Youth Federation — Western

United States, last modified March 6, 20o9, https://ayfwest.org/news/armenians-in-turkey-today-an-overview/. Esayan, "Armenians in Turkey Today: An Overview."

49 Commission, “2004 Regular Report on Turkey’s Progress Towards Accession,” COM (2004) 656 Final, 2004.

$5^{\circ} \quad$ Karakas, “Turkey: Islam and Laicism Between the Interests of the State, Politics, and Society," 2.

51 Turan Kayaoglu, "Getting Turkey Back on Track to Democracy, Human Rights, and Religious Freedom," The Review of Faith \& International Affairs 14, no. 2 (2016), doi:10.1080/15570274.2016.1 184447 .

$5^{2}$ Kayaoglu, "Getting Turkey Back on Track to Democracy, Human Rights, and Religious Freedom," 19. 
of public employment. For the military, Islam meant ethnicity and not only religious belief. ${ }^{53}$ Therefore, some articles of the Turkish constitution of 1982 that followed the military coup were used to restrict minority rights. It did not refer to minorities except perhaps passively through Article 10, which indicated equality before the law. ${ }^{54}$ According to Yilmaz, the constitution of 1982 violated three types of Non-Muslim minority rights derived from the Lausanne Treaty, including "restrictions in education (violation of arts. 40 and 42/3); Language restrictions (' 30 os and '6os; violation of art. 40); Restrictions imposed on minority religious foundations (violation of art.42/3)." 55 The 1982 constitution did not mention the term "minorities" at all. Therefore, the 1982 constitution undermined, diminished, and marginalized the minorities defined by the Lausanne Treaty of 1923, instead of being respected by any Turkish Constitution as an internationally binding treaty. As a result, the 1982 constitution "solved" the minorities issue "without ever addressing it," as the MRGI 2007 report mentions ironically. ${ }^{56}$

To further reflect the institutionalization of adverse feelings towards non-Muslim minorities in Turkey, research conducted in 2001 by the Swedish Institute of International Affairs concluded that most Turks regard Armenians as foreigners, and Armenians still find it difficult to register their children as Armenians. ${ }^{57}$ Furthermore, Grigoriadis ${ }^{58}$ argues that Lausanne's non-Muslim minorities were deemed 'inassimilable', and therefore their economic and social marginalization and eventual coercion to emigrate became targets of long-term state policies. Moreover, Icduygu \& Soner ${ }^{59}$ emphasize that the public authorities and the Turkish public are not convinced of the loyalty of the non-Muslim minorities to Turkey. They also underline the Turkish mentality and perception of achieving a coherent national identity and the role of non-Muslim minorities in doing so. Therefore, Icduygu \& Soner ${ }^{60}$ assert that according to the Turkish authorities and the public, minority groups must first lose their influence either through assimilation, integration, or expulsion.

53 Tessa Hofmann, Armenians in Turkey Today: A Critical Assessment of the Situation of the Armenian Minority in the Turkish Republic (Brussels: The EU Office of Armenian Associations of Europe, 2002), 18.

Laure Almairac and Paula Tscherne-Lempiäinen, Turkey: A Minority Policy of Systematic Negation (Helsinki: International Helsinki Federation for Human Rights (IHF), 2006). Yilmaz, "Is there a Puzzle?: Compliance With Minority Rights in Turkey (1999-2010)," 11.

56 Kurban, "A Quest for Equality: Minorities in Turkey," 10.

57 Karimova and Deverell, "Minorities in Turkey."

$5^{8}$ Ioannis N. Grigoriadis, "On the Europeanization of Minority Rights Protection: Comparing the Cases of Greece and Turkey," Mediterranean Politics 13, no. 1 (2008), doi:10.1080/13629390701862574. 


\section{The Current Situation of Christian Minorities in Turkey (Armenian and Greek Orthodox Turkish citizens)}

The EU-Turkey 2010 Progress Report best describes the current non-Muslim minority situation in Turkey. According to the report, freedom of worship continues to be generally respected. However, it states that "Non-Muslim communities — as organised structures of religious groups - still face problems due to lack of legal personality;" 61 a problem that the non-Muslim communities have been facing since the 1970s. In June 2010, the ECtHR acknowledged the Ecumenical Patriarchate as a legal entity, ${ }^{62}$ which in turn could pave the way to the consideration of the Armenian Patriarchate as a legal entity too. Nevertheless, the problem still lies in Turkey's complete denial of the "Ecumenical" title of the Greek Patriarchy and, consequently, denies its legal status. This denial prevents the Greek Patriarchy from owning and administering cultural, educational, and other institutions that are necessary to maintain their traditions and language and have financial revenues.

On the right to property, the EU-Turkey 2010 report asserts that "the Law on foundations has been implemented, albeit with some delays and procedural problems. The Foundations Council acknowledged these problems and tried to speed up procedures. However, this law does not address the issues of properties seized and sold to third parties or properties of foundations merged before the new legislation was adopted. Turkey needs to ensure full respect for the property rights of all non-Muslim religious communities." 63 Regarding inheritance, Non-Muslim minorities still face difficulties in property inheritance issues, especially if it is between Turkish nationals belonging to the Greek minority and Greek nationals, due to "erroneous interpretations by Turkish courts of the requirement of reciprocity." 64

As for the minorities' schools, deputy principals had to be Muslim Turks until 2007, after which a new law allowed non-Muslims to hold those positions. ${ }^{65}$ Only students of a minority father can attend minority schools. Such schools still lack textbooks in the mother language and lack trained teachers because of the government's ban on publishing such books and hiring teachers from abroad.

61 Commission, “Commission Staff Working Document: Turkey 2010 Progress Reportaccompanying the Communication from The Commission to The European Parliament and The Council_Enlargement Strategy and Main Challenges 2010-2011," COM (2010) 66o, 2010, 23.

62 S. MacDonald, "Christians in Turkey Find a Champion”, Assyrian International News Agency, July 23, 2010, http://www.aina.org/news/20100722203320.htm.

63 Commission, 'Commission Staff Working Document: Turkey 2010 Progress Report,'79.

64 European Commission Against Racism and Intolerance, "ECRI report on Turkey 2011 — Fourth Monitoring Cycle," 34 .

65 Leonard Leo, and Felice D. Gaer, Annual Report of the United States Commission on International Religious Freedom Covering April 1, 2009 - March 31, 2010. Washington D. C.: U. S. Commission on International Religious Freedom, 2010, 309 
Moreover, the EU Commission continuously expresses its concerns regarding Turkey's minority rights, perhaps the latest of which was the EU Commission Turkey 2016 Report. In this report, the Commission asserts that minority rights are not sufficiently protected. Acts of hate speech against the Christian and Jewish minorities continue to be repeatedly reported, and some organizations, such as the Grey Wolves, were inspired by such hatred speeches to launch attacks against Armenians. The Turkish Nationalist Movement Party has a militant arm called the "Bozkurt" (Turkish Grey Wolves) and sometimes referred to as "Ergenekon". It is the military wing of the far-right, ultra-nationalistic, arch-Kemalis, and authoritarian network that form Turkey's "deep state" as described by Park. ${ }^{66}$ According to Jenkins, ${ }^{67}$ the Grey Wolves involves a vast network that includes military officers, members of the Turkish National Police, the judiciary, academia, and right-wing political organizations. There are numerous established links between the Turkish government and the Grey Wolves. Perhaps the most empirical link is a report released by the Turkish National Assembly's investigative committee in April 1997 following the 'Susurluk' affair of 1996, as it offered a "considerable evidence of close ties between state authorities and criminal gangs, including the use of the Grey Wolves to carry out illegal activities." 68 There are Turkish academics that attribute hundreds of extrajudicial killings and bombings in Turkey to the stay-behind organizations such as the Grey Wolves, including the assassinations of "numerous journalists and famous public intellectuals including Hrant Dink [the prominent Armenian journalist assassinated in Istanbul on January 19, 2007], (Uğur Mumcu, Bahriye Üçok, and Abdi İpekçi)." ${ }^{9}$ In 2015, Tolga Adigüzel, the Kars provincial head of the Grey Wolves, was sentenced to jail for making remarks to 'go on for an Armenian hunt' following a concert in 2015 by an Armenian pianist in the city of Ani. ${ }^{70}$ Moreover, two weeks following a mass held at the Armenian Holy Cross Church in Akhdamar (also discussed in section 3.1) in 2010 for the first time since 1915, the Grey Wolves got permission from the government to pray at the same sight in Ani. Hundreds of Grey Wolves members led by Devlet Bahceli gathered at the Armenian Church site in Ani. They shouted, "Allah Akbar" and "knelt before an imam amidst the cathedral ruins." According to Marchand and Perrier, ${ }^{71}$ the Grey Wolves' message was clear, "Anatolia is a Muslim,

66 Bill Park, “Turkey's Deep State," The RUSIJournal 153, no. 5 (2008), doi:10.1080/o3071840802521937.

67 Gareth. H. Jenkins, "Between Fact and Fantasy: Turkey's Ergenekon Investigation," Silk Road paper, Central Asia-Caucasus Institute, Johns Hopkins University, Washington, D.C., Aug. 2009.

68 Park, “Turkey's Deep State," 54.

69 Akin H. Unver, "Turkey's "Deep-State" and the Ergenekon Conundrum," The Middle East Institute Policy Brief No. 23, April 2009. Aykan ERDEMIR and Merve TAHIROGLU, “Turkish Grey Wolves Target 'Chinese,” POLITICO, last modified July 30, 2015, https://www.politico.eu/article/turkish-grey-wolves-targetchinese/.

71 Laure Marchand and Guillaume Perrier, Turkey and the Armenian Ghost: On the Trail of the Genocide (Montreal: McGill Queen's University Press-MQUP, 2015), 72. 
Turkish land with no Christians or churches. Even the stones must be assimilated." Furthermore, when Germany recognized the mass killings of the Armenians during WWI by the Turks as "Genocide," many of the Grey Wolves gathered at the German Consulate in Istanbul on June 2, 2016. They protested against the German recognition of the Armenian Genocide, making the "Grey Wolves" sign during the protests. ${ }^{72}$

\subsection{Armenian Orthodox}

The Armenian Genocide committed by Turkey in 1915 resulted in the loss of 1.5 million Armenian lives. Even if the subject is controversial, as argued by the Turks (planned genocide versus deportation with tragic consequences), the fact remains that a significant number of Armenians disappeared from Turkey. ${ }^{73}$ The 'disappeared' Armenians' properties remain in the hands of the Turkish government, including Armenians' lands, houses, churches, schools, monasteries, and historical monuments. Today, Turkey still intentionally and systematically destroys them or leaves them to decay in a massive effort to obliterate the memory of Anatolia's Armenian presence. By doing so, Turkey is committing cultural genocide against the Armenian heritage. For more than fifty years, "the Turkish government has used convoluted regulations and undemocratic laws to confiscate hundreds of religious minority properties, primarily those belonging to the Greek and Armenian Orthodox communities." 74 The EU—Turkey 2010 Progress Report stated that "on 19 September the first religious service since 1915 [since the Genocide] was held at the Armenian Holy Cross church on the Akhdamar Island in Lake Van." It is worth noting that the circumstances and the conditions that accompanied the mass reflect the continued lack of Turkish tolerance and respect for non-Muslim minorities' religious rights as prescribed by the EU accession conditionality. The mass took place "three years after the completion of a $\$ 1.5$ million renovation of the church funded by the Turkish government, which has allowed Turkey's Armenian community to hold religious services there once a year." 75 The Turks see it as an "important gesture towards freedom of faith." ${ }^{76}$ However, Turkish authorities did not even allow the Armenian worshipers to

72 Siobhan O'Grady, "With Germany's Armenian Genocide Vote, Has Turkey Lost Its Only Friend in Europe?," Foreign Policy, last modified June 2, 2016, https://foreignpolicy.com/2016/o6/o2/ with-germanys-armenian-genocide-vote-has-turkey-lost-its-only-friend-in-europe/. Lucian Boia, "Minority Issues: Minorities in Southeastern Europe: Legacies of the Past," in Beyond EU-Enlargement Volume 2: The Agenda of Stabilisation for Southeastern Europe Bertelsmann, ed. Wim Van Meurs (Gutersloh: Bertelsmann Foundation Publishers, 2001), 145. Freedom, 308. Radio Free Europe, “Armenian Ruling Party Slams Planned Church Service In Turkey," Radio Free Europe, last modified August 11, 2010, www.rferl.org/content/Armenian_Ruling_Party_ Slams_Planned_Church_Service_In_Turkey/2124612.html.

76 Joathan Head, "Armenian Church Brought Back to Life," BBC News, last modified September 19, 2010, https://www.bbc.co.uk/news/world-europe-11366201. 
put the holy cross on the church's roof. Moreover, Armenians were allowed to hold mass services at this church only once a year, which is an explicit limitation to the freedom of religion and worship. Robert Koptas, editor-in-chief of Agos Armenian newspaper, commented on this particular event, saying that the current government "renovated the church, which is great. But they must be braver. This was not enough. Most of Turkish society is ready to accept this is an Armenian church. Now it is the government's turn." 77 The church remains to be officially a state museum since 2007 , and the government refuses to hand it to the Armenian Patriarchate.

Currently, the Armenian Orthodox community is the largest non-Muslim minority in Turkey, with around 65,000.78 Their situation can be described as a combination of intense prejudice with an impressive range of discriminatory legal and administrative constraints. "They are regularly the target of campaigns and harassment, in which part of the media and political elite join forces to whip up public fear, resentment and anger toward an urban minority now representing at most $0.1 \%$ of the country's population and routinely blamed for the country's troubles." ${ }^{79}$ This attitude was the leading cause of many "hate crimes", including the assassination of "Agos" Armenian newspaper's editor Hrant Dink in January 2007 by a young Turkish nationalist on the basis that Dink's insulted "Turkishness" under Article 301 of the Turkish penal code by daring to declare publicly that an Armenian Genocide took place in 1915. There is a public sensitivity towards the Armenians in Turkey as "polls indicate that Armenians are the most hated people in Turkey, while $73 \%$ of Turkish children think Armenians are 'bad people"' 80 This negative attitude towards the major Non-Muslim Christian minority in Turkey causes more harassment, persecutions, and hate crimes against the Armenians, as Marissa Kuchuk and Sevag Balıkçı. Marissa Kuchuk, an 84-year-old Turkish national of Armenian origins, was brutally murdered in her apartment in Istanbul in December 2012 by stabbing her several times and carving a cross on her chest. ${ }^{81}$ Marissa's funeral instigated fears amongst the Armenian community that such violent acts will "continue being swept under the rug" 82 as authorities turn a blind eye to such crimes. Similarly, Sevag Balıkçı, a Turkish soldier of Armenian descendent, was brutally shot during his military service by another Turkish soldier on April 24, 2011, the Armenian Genocide

77

78 Burcu Gultekin-Punsmann, Cengiz Gunay, Riva Kastoryano, and Kıvanç Ulusoy, "Religious Freedom in Turkey: Situation of Religious Minorities."

79

Hofmann, Armenians in Turkey Today: A Critical Assessment of the Situation of the Armenian Minority in the Turkish Republic, 6.

80 Hofmann, Armenians in Turkey Today: A Critical Assessment of the Situation of the Armenian Minority in the Turkish Republic, 6.

81 Armenian Weekly, "Funeral of Murdered Armenian Woman in Istanbul Evokes Memories of Earlier Cover-Ups," The Armenian Weekly, last modified January 6, 2013, https://www. armenianweekly.com/2013/o1/o6/funeral-of-murdered-armenian-woman-in-istanbul-evokesmemories-of-earlier-cover-ups/.

82 Armenian Weekly, 'Funeral of Murdered Armenian Woman in Istanbul Evokes Memories of Earlier Cover-Ups.' 
commemoration day. A Turkish soldier witnessed the incident and testified before the court that Sevag was killed when the perpetrator "pointed his rifle at Sevag and pulled the trigger," 83 indicating that Sevag's death was a murder and not an accident or an act of negligence. Moreover, the Turkish soldier also testified that the perpetrator's family continually pressured him to testify in the latter's favor, ${ }^{84}$ thus obstructing justice. A military court found the perpetrator guilty of felony murder as though he shot and killed Sevag by mistake ${ }^{85}$ and did not find him guilty of first-degree murder based on premeditated murder or hate crime. Such acts by the authorities confirm the fears of the Armenian community for covering up hate crimes committed against them.

A report by the International Helsinki Federation for Human Rights (IHF) ${ }^{86}$ discusses Armenians' discrimination and harassment in Turkey as a violation of their freedom of religion and religious tolerance. The report asserts that widespread disdain towards non-Muslim minorities is an everyday occurrence and highlights the fact that it is taboo to openly and freely discuss the Genocide of 1.5 million Armenians, which is a fact that is officially denied. Furthermore, the report underlines a correlation between the Genocide denial and minority rights by stating that "this denial reflects a general reluctance to grant a minority some kind of a recognition that would differentiate them from the Turkish oneness." 87 Since Turkey still officially denies the Armenian Genocide, it ipso facto also denies any rights deriving from that. Tunuc Aybak, a Turkish scholar, states that "the denial policy has now become an integral part of the Islamic conservative Justice and Development Party's neo-Ottomanist grand strategy and its regional ambitions." ${ }^{8} 8 \mathrm{He}$ moreover asserts that the denial has led to a "gradual racialization of the Armenian other as a geopolitical threat to the Turkish national identity." 89

Therefore, being an Armenian in Turkey implies being an inferior person. Many Turks consider "Armenian" to be an insult. This attitude was reflected in a 2010 case of a Turkish journalist who received an 11-month prison sentence for "insulting" President Gul by claiming that the latter was of Armenian descent. According to human rights activists, "the fact that the Turkish president went to court for the 'insult' of being called an Armenian demonstrates the extent to which Armenians are vilified in Turkey." ${ }^{90}$

83 Today's Zaman, “Armenian private killed intentionally, new testimony shows," Today's Zaman, last modified January 27, 2012, www.todayszaman.com/news-269806-armenian-private-killed-intentionally-new-testimony-shows.html.

84 Today's Zaman, "Armenian private killed intentionally, new testimony shows."

85 Ekin Karaca, "SevagBalıkcı Was Shot By Mistake, Court Rules," Bianet-Bagimsiz Iletisim Agi, last modified March 27, 2013, https://bianet.org/english/minorities/1454O2-sevag-balikci-wasshot-by-mistake-court-rules.

86 Almairac and Tscherne-Lempiäinen, Turkey: A Minority Policy of Systematic Negation.

87 Almairac and Tscherne-Lempiäinen, Turkey: A Minority Policy of Systematic Negation, 18.

88 Tunc Aybak, “Geopolitics of Denial: Turkish State's 'Armenian Problem," Journal of Balkan and Near Eastern Studies 18, no. 2 (2016): 125, doi:10.1080/19448953.2016.1141582.

89 Aybak,"Geopolitics of Denial: Turkish State's 'Armenian Problem," 125

90 Armenian Weekly, "11-Month Prison Sentence for 'Gul is Armenian' Comment," The Armenian Weekly, last modified November 9, 2010, https://www.armenianweekly. 
Moreover, during a television interview in 2014, Mr. Recep Tayyip Erdogan, the Turkish Prime Minister at the time, complained about people questioning his family's roots and background as he stated that some called him a Georgian and "some have said something worse: they called me an Armenian." ${ }^{91}$ Both Turkish officials' reactions and rhetoric illustrate that it has become a normal subconscious reaction that can be expressed openly and blatantly, even though some officials have officially expressed otherwise. For instance, on April 23, 2014, the Turkish Prime Minister at the time, Mr. Erdogan, "offered his condolences to the descendants of the Armenians who were killed by Ottoman troops during World War I." 92

\subsection{Greek Orthodox}

There are around 3000 Greek Orthodox Turkish citizens living in Turkey today. It is worth mentioning that the Greek Orthodox Turkish citizens are different from the Muslim Greeks, who call themselves "Turkos" and label their language as "Romaika". The "Turkos" population is estimated to be around 300,00o, and they separate themselves from the Greek Orthodox by calling the latter "Oromeos." ${ }^{93}$ Minority issues are mutual between Greece and Turkey since Greece has problems with its Turkish-Muslim minority in Thrace. ${ }^{94}$ Due to its relatively small number, the Greek Orthodox community in Turkey faces the problem of preserving its faith and religion since it lacks the resources to train its clergymen. Moreover, Turkish authorities banned the Greek Orthodox community from hiring and/or recruiting non-Turkish Greek Orthodox clergymen by not issuing work permits. However, the EU-Turkey 2010 progress report mentioned that "the Turkish authorities granted Turkish citizenship to fourteen members of the Greek Orthodox clergy. This facilitates the work of the patriarchate and of the Holy Synod." The EU-Turkey 2010 progress report also mentioned that "restrictions on the training of clergy remain. The Halki (Heybeliada) Greek Orthodox seminary remains closed, although there have been positive statements by senior government officials on the possibility of re-opening it. The authorities closed the Halki seminary in 1971 with the closure of private religious training institutions due to higher education institutions' nationalization.

As for the "Ecumenical" title of the Greek Orthodox Patriarch, the 2010 EUTurkey Progress Report mentions that "the Ecumenical Patriarch is not free to use the ecclesiastical title 'Ecumenical' on all occasions." The same sentiment was also

com/2010/11/06/11-month-sentence/.

Adam Taylor, “Is ‘Armenian' an Insult? Turkey’s prime minister seems to think so," The

Washington Post, last modified August 6, 2014, http://www.washingtonpost.com/blogs/

worldviews/wp/2014/o8/o6/is-armenian-an-insult-turkeys-prime-minister-seems-to-think-so/.

94 Senem A. Duzgit, Seeking Kant in the EU's Relations with Turkey (Istanbul: Tesev Publications, 2006), 20. 
observed in the 2015 and 2016 EU-Turkey Report as it indicated that "The Ecumenical Patriarchate received no indication from the authorities that it may use the 'ecumenical' title freely." 9596 The Turkish denial of the title practically means depriving the Patriarch of his authority as a leader of 250 million Orthodox Christians worldwide. ${ }^{97}$ On June 26 , 2007, the Turkish Supreme Court of Appeals (Yargitay) ruled (2007/5603) that the Greek Patriarch was merely the representative of the church of the Greek minority in Turkey, which undermines his liturgical role as the head of the Orthodox Church worldwide. This "demotion" of the Patriarch is "perceived by members of the minority and by international observers as an attempt to diminish the importance of the Patriarchate." 98 Turkish authorities consider that this title is in conflict with the principle of secularism and therefore is a "threat for their national security" ${ }^{99}$ To absolve his government from recognizing the "Ecumenical" in the title of the Patriarch, PM Erdogan stated that the "Greek Orthodox Patriarch's use of the title 'ecumenical' should not be a matter on which the state should rule." 100

\subsection{A Paradigm Shift: Is There Any Hope for the Future of Christian Minorities in Turkey.}

Since the commencement of the new millennium, there has been a shift in Turkish public opinion regarding the protection of minority rights. For instance, a noticeable change is the open discussion of the Armenian Genocide, a topic considered taboo until 2005. According to Cheterian, ${ }^{101}$ Turkish intellectuals started discussing the Armenian Genocide after its ninetieth commemoration. Cheterian ${ }^{102}$ compares how Turkish intellectuals reacted differently towards Yasar Kemal and Belge Publishing House cases around the Genocide's ninetieth commemoration. Yasar Kemal, A Turkish Novelist of Kurdish origin, was tried before the court of law in Turkey and sentenced to

95 Commission, “Commission Staff Working Document: Turkey 2015 Progress Report— accompanying the Document Communication from The Commission to The European Parliament, the Council, The European Economic and Social Committee and The Committee of The Regions," SWD (2015) 216 Final, 2015, 63. Commission, “Commission Staff Working Document: Turkey 2016 Progress Report,” 72.

97 MacDonald, "Christians in Turkey Find a Champion."

98 Michel Hunault, "Freedom of Religion and Other Human Rights for Non-Muslim Minorities in Turkey and for the Muslim Minority in Thrace (Eastern Greece)," Report by Committee on Legal Affairs and Human Rights, Doc. 1186o, April 21,2009. Burcu Gultekin-Punsmann, Cengiz Gunay, Riva Kastoryano, and KıvançUlusoy, "Religious Freedom in Turkey: Situation of Religious Minorities," 5.

Commission, "Commission Staff Working Document: Turkey 2008 Progress Report— accompanying the Communication from The Commission to The European Parliament and The Council Enlargement Strategy and Main Challenges 2008-2009," SEC (2008) 2699, 2008, 19. VickenCheterian, Open Wounds: Armenians, Turks and a Century of Genocide (New York: Oxford University Press, 2015). 
twenty months in prison for "inciting hatred". Turkish intellectuals also reacted to the Armenian Question when Belge Publishing House and its employees faced the same fate as Yasar Kemal for publishing a book written by Yves Ternon on the Armenian Genocide. In Yasar Kemal's case, the Turkish intellectuals showed up at the courtroom to express support during the trial, and they launched a nation-wide campaign to defend Yasar Kemal. However, in the Belge Publishing House case, Turkish intellectuals did not have the same stance in Yasar Kemal's case. According to Cheterian, the Turkish intellectuals' reason to react as such was that they did not want to associate themselves with Belge or with its campaign since it published Ternon's book on the Armenian Genocide. This comparison reflects the depth of the anti-Armenian taboo in Turkey, at least until around 2005 .

Since 2005, however, some grassroots activities initiated on a personal level have supported Christian Minority Rights. Nevertheless, whoever dares to raise such sensitive subjects publicly faces prosecution and persecution. For instance, during an interview with a Swiss newspaper in 2005, Orhan Pamuk, a Nobel Prize-winning Turkish writer, acknowledged that a million Armenians and 30,0oo Kurds were killed in Turkey and that he is the only one who dares to talk about it. Soon after the interview, Pamuk was demonized by the Turkish press and was called a traitor for raising public awareness about the Armenian Genocide. He received life threats and was forced to flee Turkey. When he returned to Turkey a few years later, he was prosecuted and charged with "public denigration of Turkish identity." ${ }^{103}$ Similarly, Elif Shafak, a bestselling Turkish author and the writer of the "Bastard of Istanbul" in which one of the characters refers to the deaths of Armenians during the First World War as "Genocide," faced charges of "insulting Turkishness" in 2006 under article 301 of the Penal Code because of mentioning the Armenian Genocide. ${ }^{104}$ Although both Orhan Pamuk and Elif Shafak were prosecuted for insulting Turkishness, both authors could have inspired more like-minded people to think about what happened in 1915 and therefore adopt a more tolerant approach towards the Armenian population in Turkey. In 2008, a group of about 200 Turkish intellectuals, including prominent academics, journalists, writers, and artists, issued an apology on the Internet for the World War I-era massacres of Armenians in Turkey. ${ }^{105}$ They avoided using the term "Genocide" in their apology, and used the term "Great Catastrophe" instead.

There are some aspects of hope for Christians' future in Turkey, especially for the Armenian component of Turkish society. A public opinion poll conducted by The

103 Maureen Freely, “I Stand by My Words. And Even More, I Stand by My Right to Say Them...,"

The Guardian, last modified October 23, 2005, https://www.theguardian.com/world/2005/ oct/23/books.turkey.

104 Almairac and Tscherne-Lempiäinen, Turkey: A Minority Policy of Systematic Negation.

105 Associated Press, "Turks Apologize for Armenian Massacres: Prominent Intellectuals Show Regret Online for World War I-Era Atrocities," NBC News, last modified December 15, 2008, https://www.nbcnews.com/id/wbna28240840\#.Wrp7TojwZPa\%2oedam.org.tr/en/turks-regretful-over-the-armenian-tragedy-of-1915-but-refuse-to-qualify-it-as-a-genocide/. 
Centre for Economics and Foreign Policy Studies (EDAM) ${ }^{106}$ in 2015 on the centennial of the Armenian Genocide, reflects that only 9 percent of the participants want the Turkish government to accept the claims of Genocide, whereas another 9 percent favor an apology. Therefore, these results reflect a slight change in the Turkish perception towards the Armenian community in Turkey as there are some, yet still only a small minority of Turkish citizens who are willing to accept the Genocide as such and apologize to the Armenians accordingly.

\section{Conclusion}

Turkey has been adopting numerous reforms in compliance with EU conditionality requirements, including reforms related to minority rights, reforms in the forms of amendments applied to its 1982 constitution, and reforms of its domestic laws. These reforms are not more than a cosmetic attempt to correct a problem that requires a much more substantive solution. In order to be accepted into the EU, Turkey, among other things, needs to address the non-Muslim minority question more seriously instead of adding ineffective amendments to its constitution and laws. It is apparent that an adverse sentiment towards the non-Muslim minorities is still prevalent in Turkey and institutionalized and deeply rooted in Turkish society. Although intolerance of minorities is still ever-present in Turkish consciousness, this has been changing slowly since 2005. Turkey still has a long path to reach the required EU standard of tolerance toward its non-Muslim minorities. That, in turn, requires more time, effort, courage, and resources to openly discuss issues related to minorities in general and non-Muslim minorities in particular. Therefore, Turkish society has to abolish the alienation and the demonization of the "others" by adopting more tolerable textbooks reflecting diversity, especially those related to the Diyanat Plan. This process would help demystify minorities and accept them as an integral and equal part of Turkish society. Additionally, Turkish authorities have to stop cultural genocide against the Greek and Armenian cultural sites and heritage and allow both communities to hold masses in their historical churches. Turkish authorities will also have to address hate crimes against minorities by neutralizing the hatred and superiority feelings against them and abolish the secret racial codes. Such steps would help change Turkish society's perceptions about the "other" (minorities), which has been partially based on myths and social dominance through which minorities are stereotyped as untrustworthy, traitorous, and harmful to the state.

To take the non-Muslim minority question seriously and consider minorities as a source of diversity, pluralism, and wealth within the Turkish society rather than a threat, Turkey must reconcile with its past to cope with its present and prepare for a better future. That, in turn, facilitates Turkey's EU accession process. Therefore, Turkey

106 EDAM, "Turks Regretful over the Armenian Tragedy of 1915 but Refuse to Qualify It As a Genocide," Edam, last modified January 1, 2015, https://edam.org.tr/en/turks-regretful-overthe-armenian-tragedy-of-1915-but-refuse-to-qualify-it-as-a-genocide/. 
has to take some significant measures, including but not limited to acknowledging the Armenian Genocide; recognizing the "Ecumenical" nature of the Greek Orthodox Patriarch; reopening the Halki (Heybeliada) Greek Orthodox seminary; and giving more autonomy and freedom not only to the non-Muslim minorities but also to the Muslim minorities including the Alawites and the Kurds. Only by taking such steps in relation to its minorities, Turkey will fulfill part of the political criterion of the Copenhagen Criteria, and therefore be eligible for the EU accession.

\section{Bibliography}

Almairac, Laure, and Paula Tscherne-Lempiäinen. Turkey: A Minority Policy of Systematic Negation. Helsinki: International Helsinki Federation for Human Rights (IHF), 2006.

Armenian Weekly. "11-Month Prison Sentence for 'Gul is Armenian' Comment." The Armenian Weekly. Last modified November 9, 2010. https://www.armenianweekly. com/2010/11/o6/11-month-sentence/.

Armenian Weekly. "Funeral of Murdered Armenian Woman in Istanbul Evokes Memories of Earlier Cover-Ups." The Armenian Weekly. Last modified January 6, 2013. https://www.armenianweekly.com/2013/o1/o6/funeral-of-murdered-armenian-woman-in-istanbul-evokes-memories-of-earlier-cover-ups/.

Associated Press. "Turks Apologize for Armenian Massacres: Prominent Intellectuals Show Regret Online for World War I-Era Atrocities.” NBC News. Last modified December 15, 2008. https://www.nbcnews.com/id/wbna28240840\#. Wrp7TojwZPa\%2oedam.org.tr/en/turks-regretful-over-the-armenian-tragedyof-1915-but-refuse-to-qualify-it-as-a-genocide/.

Aybak, Tunc. "Geopolitics of Denial: Turkish State's 'Armenian Problem." Journal of Balkan and Near Eastern Studies 18, no. 2 (2016), 125-44. doi:10.1080/19448953.20 16.1141582 .

Barkey, Karen, and George Gavrilis. "The Ottoman Millet System: Non-Territorial Autonomy and its Contemporary Legacy." Ethnopolitics 15, no. 1 (2016), 24-42. do i:10.1080/17449057.2015.1101845.

Baylies, Carolyn. "'Political conditionality' and democratisation." Review of African Political Economy 22, no. 65 (1995), 321-37. doi:10.1080/03056249508704143.

Boia, Lucian. "Minority Issues: Minorities in Southeastern Europe: Legacies of the Past." In Beyond EU-Enlargement Volume 2: The Agenda of Stabilisation for Southeastern Europe Bertelsmann, edited by Wim Van Meurs, 139-54. Gutersloh: Bertelsmann Foundation Publishers, 2001.

Brown, Adele, and Michael Attenborough. "EU Enlargement: The Western Balkans." House of Commons Library Working paper 07/27, 2007.

Chelala, Cesar. "Erdogan's Apology." CounterPunch.org. Last modified April 25, 2014. https://www.counterpunch.org/2014/04/25/erdogans-apology/.

Cheterian, Vicken. Open Wounds: Armenians, Turks and a Century of Genocide. New York: Oxford University Press, 2015. 
Commission, “2003 Regular Report on Turkey's Progress Towards Accession,” SEC (2003) 1212 Final, 2003.

Commission, “2004 Regular Report on Turkey's Progress Towards Accession," COM (2004) 656 Final, 2004.

Commission, "Commission Staff Working Document: Turkey 2008 Progress Report - accompanying the Communication from The Commission to The European Parliament and The Council Enlargement Strategy and Main Challenges 2008-2009," SEC (2008) 2699, 2008.

Commission, "Commission Staff Working Document: Turkey 2010 Progress Report - accompanying the Communication from The Commission to The European Parliament and The Council-Enlargement Strategy and Main Challenges 2010-2011," COM (2010) 66o, 2010.

Commission, "Commission Staff Working Document: Turkey 2014 Progress Reportaccompanying the Document Communication from The Commission to The European Parliament, the Council, The European Economic and Social Committee and The Committee of The Regions," COM (2014) 700 Final, 2014.

Commission, "Commission Staff Working Document: Turkey 2016 Progress Reportaccompanying the Document Communication from The Commission to The European Parliament, the Council, The European Economic and Social Committee and The Committee of The Regions," SWD (2016) 366 Final, 2016.

Commission, "Communication from the Commission-2005 enlargement strategy paper," COM (2005) 0561 Final, 2005.

Commission, "Communication from The Commission to The European Parliament and The Council: Enlargement Strategy and Main Challenges 2006-2007," COM (2006) 649, 2006.

Commission, "Regular Report on Turkey's Progress Towards Accession," COM (2002) 700 Final, 2002.

Commission, “Turkey: 2005 Progress Report," COM (2005) 561 Final, 2005.

Commission, "Commission Staff Working Document: Turkey 2015 Progress Reportaccompanying the Document Communication from The Commission to The European Parliament, the Council, The European Economic and Social Committee and The Committee of The Regions," SWD (2015) 216 Final, 2015

Dimitrova, Antoaneta. "Enlargement, Institution-Building and the EU's Administrative Capacity Requirement." West European Politics 25, no. 4 (2002), 171-9o. doi:10.1080/713601647.

Dimitrova, Antoaneta. "The New Member States of The EU in The Aftermath Of Enlargement: Do New European Rules Remain Empty Shells?" Journal of European Public Policy 17, no. 1 (2010), 137-48. doi:10.1080/1350176o9o3464929.

Dink, Hrant. "The Water Finds Its Crack: an Armenian in Turkey." Open Democracy. Last modified January 19, 2012. https://www.opendemocracy.net/en/europe_turkey_ armenia_3118jsp/. 
Docent, Robertas P. "The Enlargement of The European Union and the (Non) Membership of Turkey." European Scientific Journal 10, no. 22 (2014), 393-413. doi:10.19044/esj.2014.v1on22p\%25p.

Duzgit, Senem A. Seeking Kant in the EU's Relations with Turkey. Istanbul: Tesev Publications, 2006.

EDAM. "Turks Regretful over the Armenian Tragedy of 1915 but Refuse to Qualify It as a Genocide." Edam. Last modified January 1, 2015. https://edam.org.tr/en/ turks-regretful-over-the-armenian-tragedy-of-1915-but-refuse-to-qualify-it-as-agenocide/

Emmert, Frank, and Sinisa Petrovic. "The Past, Present, and Future of EU Enlargement.” Fordham International Law Journal 37, no. 5 (2014), 1349-419. https://ir.lawnet. fordham.edu/ilj/vol37/iss5/2.

Erdemir, Aykan, and Merve, Tahiroglu. "Turkish Grey Wolves Target 'Chinese'." POLITICO. Last modified July 30, 2015. https://www.politico.eu/article/turkishgrey-wolves-target-chinese/.

Esayan, Ari. "Armenians in Turkey Today: An Overview." Armenian Youth FederationWestern United States. Last modified March 6, 2009. https://ayfwest.org/news/ armenians-in-turkey-today-an-overview/.

European Commission Against Racism and Intolerance. "ECRI report on Turkey 2011Fourth Monitoring Cycle.” Council of Europe. Last modified February 8, 2011. https://rm.coe.int/fourth-report-on-turkey/168o8b5c7e.

Freely, Maureen. "I Stand by My Words. And Even More, I Stand by My Right to Say Them...” The Guardian. Last modified October 23, 2005. https://www.theguardian. com/world/2005/oct/23/books.turkey.

Galbreath, David J., and Joanne McEvoy. "How Epistemic Communities Drive International Regimes: The Case of Minority Rights in Europe." Journal of European Integration 35, no. 2 (2012), 169-86. doi:10.1080/o7036337.2012.692117.

Galbreath, David J., and Joanne McEvoy. The European Minority Rights Regime: Towards a Theory of Regime Effectiveness. Hampshire: Palgrave Macmillan, 2012.

Gateva Eli. "Post-Accession Conditionality: Support Instrument for Continuous Pressure?” KFG Working Paper No. 18, 2010.

Grigoriadis, Ioannis N. "On the Europeanization of Minority Rights Protection: Comparing the Cases of Greece and Turkey." Mediterranean Politics 13, no. 1 (2008), 23-41. doi:10.1080/13629390701862574.

Gultekin-Punsmann Burcu, Gunay Cengiz, Kastoryano Riva, and Ulusoy Kıvanç, "Religious Freedom in Turkey: Situation of Religious Minorities," The European Parliament's Committee on Foreign Affairs-Policy Department External Policies, Briefing Paper, Brussels, European Parliament, 2008.

Head, Jonathan. "Armenian Church Brought Back to Life." BBC News. Last modified September 19, 2010. https://www.bbc.co.uk/news/world-europe-11366201.

Hofmann, Tessa. Armenians in Turkey Today: A Critical Assessment of the Situation of the Armenian Minority in the Turkish Republic. Brussels: The EU Office of Armenian Associations of Europe, 2002. 
Hunault Michel, "Freedom of religion and other human rights for non-Muslim minorities in Turkey and for the Muslim minority in Thrace (Eastern Greece)", Report by Committee on Legal Affairs and Human Rights, Doc. 1186o, 21 April 2009 .

Hurriyet Daily News. “Turkish Interior Ministry confirms 'race codes' for minorities." Hürriyet Daily News. Last modified August 2, 2013. www.hurriyetdailynews. com/turkish-interior-ministry-confirms-race-codes-for-minorities. aspx? pageID=238\&nID=51898\&NewsCatID=339.

Icduygu, Ahmet, and B. Ali Soner. "Turkish minority rights regime: Between difference and equality." Middle Eastern Studies 42, no. 3 (2006), 447-68. doi:10.1080/00263200500521370.

Icduygu, Ahmet, SuleToktas, and B. Ali Soner. "The politics of population in a nation-building process: emigration of non-Muslims from Turkey." Ethnic and Racial Studies 31, no. 2 (2008), 35-89. doi:10.1080/01419870701491937.

Jenkins H. Gareth, "Between Fact and Fantasy: Turkey's Ergenekon Investigation," Silk Road paper, Central Asia-Caucasus Institute, Johns Hopkins University, Washington, D.C., Aug. 2009.

Kalaycıoglu Ersin, “The Political Criteria: Fair or Strict Conditionality?” Conference on Turkey, the EU and the 2004 Milestone: Is this Time for Real? (Oxford: St. Antony's College, University of Oxford, 2003)

Karaca, Ekin. "Sevag Balıkcı Was Shot by Mistake, Court Rules." Bianet-Bagimsiz Iletisim Agi. Last modified March 27, 2013. https://bianet.org/english/ minorities/145402-sevag-balikci-was-shot-by-mistake-court-rules.

Karakas Cemal, "Turkey: Islam and Laicism Between the Interests of the State, Politics, and Society," PRIF Reports No. 78, 2007.

Karimova Nigar, and Deverell Edward, "Minorities in Turkey," Occasional papers No. 19, the Swedish institute for international affairs, Stockholm, The Swedish Institute of International Affairs, 2001.

Kasaba, Resat. "Kemalist Certainties and Modern Ambiguities." In Rethinking Modernity and National Identity in Turkey, edited by Sibel Bozdogan and Resat Kasaba, 15-36. Seattle: University of Washington Press, 1997.

Kayaoglu, Turan. "Getting Turkey Back on Track to Democracy, Human Rights, and Religious Freedom.” The Review of Faith \& International Affairs 14, no. 2 (2016), 14-22. doi:10.1080/15570274.2016.1184447.

Killick, Tony. Aid and the Political Economy of Policy Change. London: Routledge, 1998. Kurban Dilek, "A Quest for Equality: Minorities in Turkey," Minority Rights Group International Report, United Kingdom, 2007.

Leo Leonard, and Gaer D. Felice, Annual Report of the United States Commission on International Religious Freedom Covering April 1, 2009-March 31, 2010. Washington, D.C.: U. S. Commission on International Religious Freedom, 2010.

MacDonald, S., "Christians in Turkey Find a Champion." Assyrian International News Agency, July 23, 2010, http://www.aina.org/news/20100722203320.htm. 
Marchand, Laure, and Guillaume Perrier. Turkey and the Armenian Ghost: On the Trail of the Genocide. Montreal: McGill Queen's University Press-MQUP, 2015.

O'Grady, Siobhan. “With Germany's Armenian Genocide Vote, Has Turkey Lost Its Only Friend in Europe?" Foreign Policy. Last modified June 2, 2016. https://foreignpolicy. com/2016/o6/o2/with-germanys-armenian-genocide-vote-has-turkey-lost-itsonly-friend-in-europe/.

Park, Bill. “Turkey's Deep State." The RUSI Journal 153, no. 5 (2008), 54-59. doi:10.1080/o3071840802521937.

Radio Free Europe. "Armenian Ruling Party Slams Planned Church Service in Turkey." Radio Free Europe. Last modified August 11, 2010. www.rferl.org/content/ Armenian_Ruling_Party_Slams_Planned_Church_Service_In_Turkey/2124612. html.

Rumford, Chris. "Resisting Globalization?: Turkey-EU relations and human and political rights in the context of the cosmopolitan democratization." International Sociology 18, no. 2 (2003), 379-94. doi:10.1177/0268580903018002004.

Sasse, Gwendolyn. "The politics of EU conditionality: the norm of minority protection during and beyond EU accession." Journal of European Public Policy 15, no. 6 (2008), 842-6o. doi:10.108o/1350176080219658o.

Sasse, Gwendolyn. "EU Conditionality and Minority Rights: Translating the Copenhagen Criterion into Policy." European University Institute (EUI) Working Paper RSCAS, 2005/16. Italy: EUI, 2005

Sassounian, Harut. "Sassounian: Istanbul Armenians Document Violations of Minority Rights in Turkey." The Armenian Weekly. Last modified March 1, 2011. https://www. armenianweekly.com/2011/o3/o1/sassounian-istanbul-armenians-documentviolations-of-minority-rights-in-turkey/.

Szocsik, Edina. "The EU Accession Criteria in the Field of Minority Protection and the Demands of Ethnic Minority Parties." Journal on Ethnopolitics and Minority Issues in Europe:JEMIE 11, no. 2 (2012), 104-27.

Taylor, Adam. “Is 'Armenian' an Insult? Turkey's Prime Minister Seems to Think So.” The Washington Post. Last modified August 6, 2014. http://www.washingtonpost.com/ blogs/worldviews/wp/2014/o8/o6/is-armenian-an-insult-turkeys-prime-ministerseems-to-think-so/.

Today's Zaman. "Armenian Private Killed Intentionally, New Testimony Shows." Today's Zaman. Last modified January 27, 2012. www.todayszaman.com/ news-2698o6-armenian-private-killed-intentionally-new-testimony-shows.html.

Toksabay, Ece, and Tulay Karadeniz. "EU Parliament Calls for Turkey Accession Talks to Be Suspended." Reuters. Last modified July 6, 2017. https://www.reuters.com/ article/us-turkey-eu-parliament/eu-parliament-calls-for-turkey-accession-talksto-be-suspended-idUSKBNigRig4.

Toktas, Sule. "EU enlargement conditions and minority protection: a reflection on Turkey's non-Muslim minorities." East European Quarterly 40, no. 4 (2006), 489-518. http://citeseerx.ist.psu.edu/viewdoc/download; jsessionid= oF9AB655138BE33 BoAAo26Fo842D4B36o?doi=10.1.1.716.934\&rep=rep1\&type=pdf. 
Unver H. Akin, "Turkey's "Deep-State" and the Ergenekon Conundrum,", The Middle East Institute Policy Brief No. 23, April 20o9.

Usul, Ali R. Democracy in Turkey: The Impact of EU Political Conditionality. London: Routledge, 2011.

Veebel, V. "European Union's Positive Conditionality Model in Pre-Accession Process." TRAMES: A Journal of the Humanities \& Social Sciences 13, no. 3 (2009), 207-31. doi:10.3176/tr.2009.3.02.

Yackley, Joseph. "Turkey, The EU and Democracy: How Public Opinion Divides Ankara and Brussels." Last modified 2008. https://www.files.ethz.ch/isn/50025/17_ casestudy_turkeyandtheeu.pdf.

Yilmaz Gozde. "Is there a Puzzle?: Compliance With Minority Rights in Turkey (19992010)," KFG working paper no. 23, Berlin, 2011.

Zurcher, E. J., and H. Van Der Linden. The European Union, Turkey and Islam. Amsterdam: Amsterdam University Press, 2004.

\section{(2)}

Isaac Andakian is an expert in Lebanese, Levantine, and MENA law, politics, and culture. His educational background extends to two master's degrees in political science and human rights and democratization, and a Juris Doctor degree. Currently, Isaac is a PhD Student at Kennesaw State University in International Conflict Management. Isaac's research interests include the Middle East and North Africa, the Arab Spring, Violence, Mass Mobilization, Youth, and Counter-Terrorism. Prior to his graduate experience, Isaac worked for sixteen years in public and private sectors in Lebanon, United States, and Cayman Islands. Isaac speaks fluent Arabic, English, and Armenian. He also speaks conversational French and Turkish.

Acknowledgements: The author would like to thank Professor Dimitris Papadimitriou, Dr. Fares Zaatar, and Attorney Shelley White for their editing assistance, and Professor Volker Franke for his insight and conceptual inspiration. 


\title{
Розширення EC, Умови і Захист Християнських Меншин в Туреччині
}

\author{
Ісаак Андакян \\ докторант \\ Державний Університет Кеннесо, Сполучені Штати
}

\begin{abstract}
Анотація
Туреччина мала бажання доєднатися до Європейського Союзу (ЄC) і стати частиною Європи $3195^{8}$ року. Останні хвилі розширення ЄС в 2004, 2007 та 2013 роках доєднало до Союзу більшість східноєвропейських держав, однак, не Туреччину. Туреччина повинна дотримуватися численних умов розширення, встановлених ЄС, для того, щоб здобути статус потенційного кандидата в члени. 3поміж цих умов - Копенгагенські критерії, які включають, однак не обмежуються повагою до прав меншин як невід'ємної політичної частини цих критеріїв. Ця стаття присвячена аналізу поваги до прав меншин в Туреччині як умови для іiї вступу до ЄС, і фокусується на немусульманських меншинах, переважно вірменських та грецьких меншинах. Висновки цієї статті демонструють переслідування та нетолерантність стосовно цих меншин як в минулому, так і в сьогоденні в турецькому суспільстві та з боку чинного турецького уряду та його попередників. В статті робиться висновок, що Туреччина не дотримується умов щодо поваги до прав меншин, які передбачені Копенгагенськими критеріями як передумова для її долучення до ЄС.
\end{abstract}

Ключові слова: умови ЄС, вступ до ЄС, Туреччина, права меншин, вірмени, греки 